\title{
Riggia puyensis n. sp. (Isopoda: Cymothoidae) parasitizing Chaetostoma breve and Chaetostoma microps (Siluriformes: Loricariidae) from Ecuador
}

\author{
C. Rodríguez-Haro*,1, M.M. Montes ${ }^{1}$, P. Marcotegui, S.R. Martorelli \\ Centro de Estudios Parasitológicos y Vectores (CEPAVE), Consejo Nacional de Investigaciones Científicas y Técnicas, Universidad Nacional de La Plata (CCT, \\ CONICET-UNLP), Calle $120 \mathrm{~s} / \mathrm{n}$ e/61 y 62, 1900, Argentina
}

\section{A R T I C L E I N F O}

\section{Article history}

Received 18 November 2016

Accepted 17 December 2016

Available online 21 December 2016

\section{Keywords:}

Parasites

Crustacea

Riggia

Ecuador

Armoured catfish

\begin{abstract}
A B S T R A C T
A new isopod was found parasitizing Chaetostoma breve and Chaetostoma microps from the Puyo and Bobonaza rivers. The parasite found belongs to the Cymothoidae family and could be located within the genus Riggia instead of Artystone by the presence of abdominal plates fused with the telson. The specimens found represent a new species, Riggia puyensis n. sp., and could be distinguished from Riggia cryptocularis by the presence of developed eyes. The main difference of the new specie from Riggia nana and Riggia brasiliensis is the size, bigger compared with the first and smaller compared with the last species. Riggia acuticaudata have the maxilliped with simple setae, the palp without spination, and maxillule with five spines (two terminal and three subterminal) instead in $R$. puyensis $\mathrm{n}$. sp. the maxilliped have plumose setae, the palp have spination (with one apical spine, two setae on middle article and one in the basal article) and the maxillule have five spines: two terminal, two subterminal and other spine lower to the others. Riggia paranaensis have similar size, same number of segments in the antena, and similar maxilla to R. puyensis $\mathrm{n}$. sp., but the antennule in the new specie have seven segments instead 6 in $R$. paranaensis, the antennule and antenna present spines not mentioned in $R$. paranaensis. Besides, the relative position of the mandible in $R$. puyensis $\mathrm{n}$. $\mathrm{sp}$. is different compared with $R$. paranaensis, the maxillule have the same number of spines but with different disposition, and the maxilliped have simple setae in $R$. paranaensis but those are plumose in the new specie.
\end{abstract}

(C) 2016 Elsevier B.V. All rights reserved.

\section{Contents}

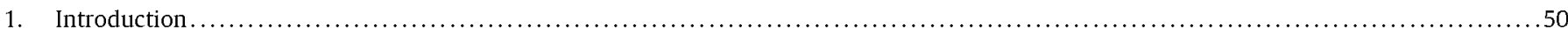

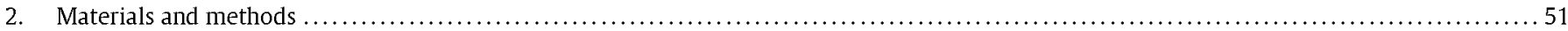

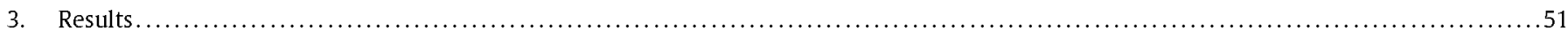

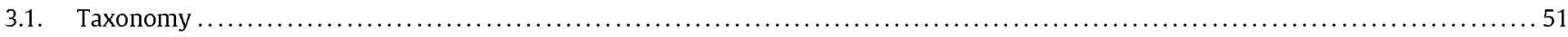

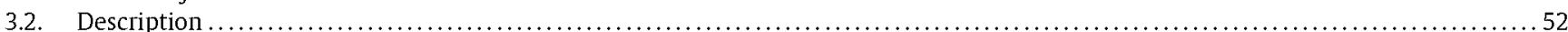

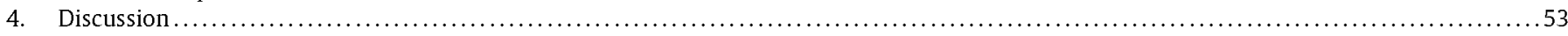

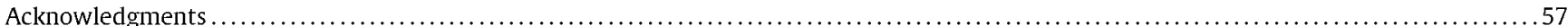

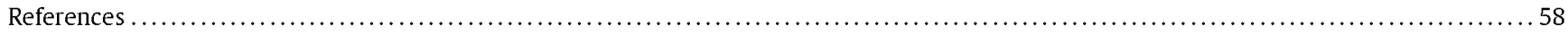

\section{Introduction}

In South America, the family Cymothoidae is well represented in freshwaters fishes. There exist two similar genera, Artystone and

\footnotetext{
* Corresponding author.

E-mail address: cerh81@yahoo.com.ar (C. Rodríguez-Haro).

1 These authors contributed equally to the work.
}

Riggia. The main difference between them are the five abdominal plates fused, with the unciform and convex telson, forming an abdominal plate in Riggia; by the other hand are the abdominal segments are free, independent one from the others and big hart-shaped telson in Artystone (Szidat, 1948).

At the moment the genus Riggia Szidat, 1948 includes five species, all parasites of freshwater fish distributed in South America: Riggia paranaensis described on Cyphocharax platanus from 


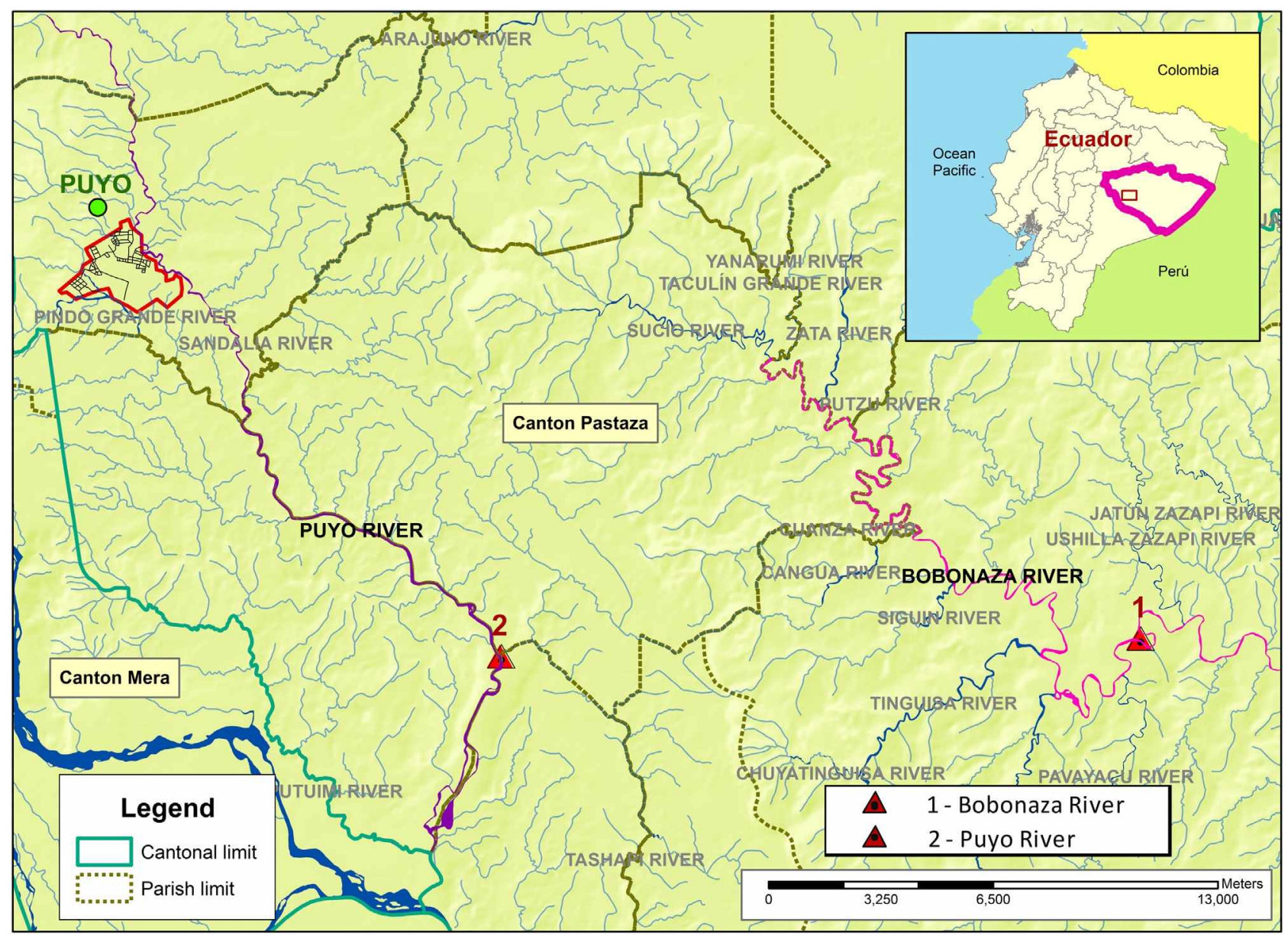

Fig. 1. Map of the sampling site in the Bobonaza (1) and Puyo River (2).

Argentina (Szidat, 1948) and later reported on Cyphocharax gilbert from Brazil (Bastos and Thatcher, 1997; Lins et al., 2008); Riggia brasiliensis on Leporinus copelandii, Leporinus octofasciatus, Leporellus vitattus, and Schiozodon nasutus from Brazil (Szidat and Schubart, 1960); Riggia nana on L. vitattus, L. striatus, and S. nasutus from Brazil (Szidat and Schubart, 1960); Riggia acuticaudata on Ancistrus sp. from Brazil (Oda et al., 2015; Thatcher et al., 2002); and Riggia cryptocularis on Odontostilbe paraguayensis and Ancistrus sp. from Brazil (Thatcher et al., 2003).

Since the finding of Asotana splendida from the Napo River (Leigh-Sharpe, 1937), only two other isopods were reported on fishes from Ecuador: Riggia sp. parasitizing Chaetostoma sp. and Rhamdia quelen (Anaguano-Yancha and Brito, 2015) and Artystone trysibia on a loricariid Chaetostoma dermorhynchum from the Amazonian region of Ecuador (Junoy, 2015).

The main objective of this paper is to describe a new species of Riggia on Chaetostoma breve and Chaetostoma microps from two rivers of Ecuador.

\section{Materials and methods}

Specimens of Chaetostoma breve and Chaetostoma microps (Table 1) were obtained by an artisanal fishermen and collected by hand and cast nets, between January 2013 and March 2016 from the Bobonaza ( $1^{\circ} 35^{\prime} 06.8^{\prime}$ S, $77^{\circ} 44^{\prime} 15.5^{\prime \prime} \mathrm{W}$ ) and Puyo (1॰35’22.7” S, 77 54'13.6" W) Rivers (Fig. 1). Those rivers are in the Pastaza Province, located near to Peru and almost in the middle of Ecuador, in the Ecuadorian Amazon region. The headwaters of the rivers are located in the middle-central and high-central Andes Mountain flowing to the south and discharge into bigger rivers, first in the Pastaza, then in the Marañon, and finally in the Amazonas (Ortega et al., 2012). There is an alternation of seasons: the rainiest season (from May to June), a dry season (from July to September), a small rainy season (from September to January) and lastly a second dry season (from February to may). There is a "fish season" when the migratory fishes from the south arrive, this occurs between August and January (Sirén, 2004).

The fishes were inspected macroscopic and only the parasitized were carried to the lab and then sacrificed. The pleopod of the female Riggia was searched for the males, but only three was found. The appendices of the female were removed, cleared in Lactophenol, observed, photographed and drawn with Olympus microscope Bx51 equipped with a drawing tube and with an AmScope MU $100010 \mathrm{MP}$ digital microscope camera. To calculate the prevalence, mean intensity and abundance were used only the females of Riggia sp.

The type material was deposited in the Invertebrate Collection of the Museo de la Plata.

\section{Results}

The host specie, provenance, prevalence, mean intensity and abundance are provided in Table 1 . The isopod was located behind the pectoral fins in the right or left side of the fishes (Fig. 2A-B).

\subsection{Taxonomy}

Order Isopoda Latreille, 1817 
Table 1

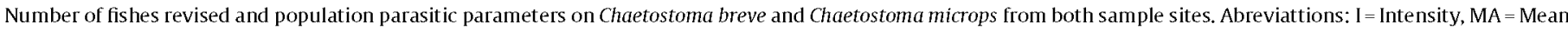
abundance, $\mathrm{N}$ = number of fishes revised (number of fishes parasite), $\mathrm{P}=$ Prevalence, * the number of fishes were not counted.

\begin{tabular}{|c|c|c|c|c|c|c|c|c|}
\hline & \multicolumn{4}{|c|}{ Puyo River } & \multicolumn{4}{|c|}{ Bobonaza River } \\
\hline & $\mathrm{N}$ & $\mathrm{P}$ & I & MA & $\mathrm{N}$ & $\mathrm{P}$ & I & MA \\
\hline Chaetostoma microps & $117(4)$ & 3,41 & 1 & 0,03 & $67(1)$ & 1,49 & 1 & 0,02 \\
\hline Chaetostoma breve* & & & & & $52(2)$ & 3,85 & 1 & 0,04 \\
\hline
\end{tabular}

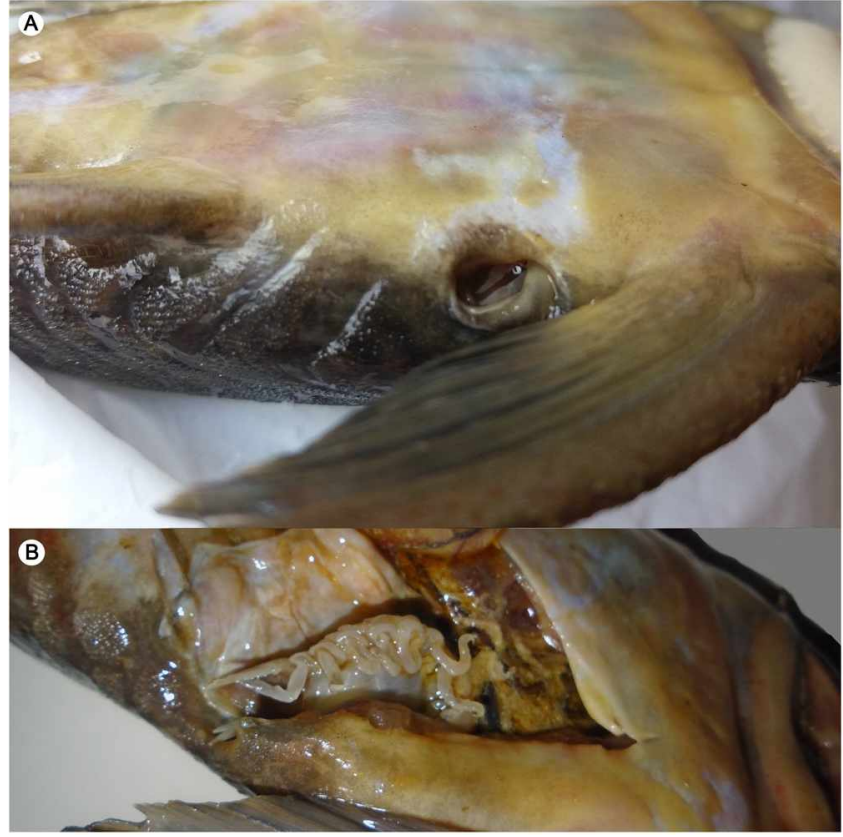

Fig. 2. Parasitized hosts of Chaetostoma breve and Chaetostoma microps from Bobonaza River and Puyo River, Ecuador. A, lateral view of host showing the lateral opening, close to the left pectoral fin. B, ventral view of dissected host showing the female of Riggia puyensis n. sp.

Suborder Cymothoida Wägele, 1989

Family Cymothoidae Leach, 1818

Genus Riggia, Szidat, 1948

Riggia puyensis n.sp. (Fig. 2-7, Table 2).

\subsection{Description}

Riggia puyensis n. sp.

(Figs. 3-11)

Diagnosis: Riggia puyensis n.sp. is characterized by a large female size; presence of developed eyes; pleotelson sharp; orientation and conformation of mandible and palp; presence of plumose seta in maxilliped; scales with hairs on maxilla; maxillule, pereopods and pleopods spines conformation.

Female description (measurements Table 2): Body convex dorsally, high in lateral view (Fig. 3A-D), with pigmentation in the outer face of pereonites. Pleotelson subtriangular, base subquadrangular.

Cephalon immersed in pereonite 1 with notable eyes. Antennule 7 segmented with a seta and finishing spine. (Figs. $4 \mathrm{~A}$ and 5 A). Antenna with 8 segments, the last reduced and with numerous apical setae (Figs. 4 B and 5 B). Mouthparts: Maxilliped (Fig. 4C) with lateral, long and plumose setae (4D) and a small, terminal, robust spine, apically softly bifid (Fig. 4E). Maxillule with 5 recurved spines, three terminals, one subterminal and other bellow (Fig. 4F and $G$ ). Maxilla bilobed terminally with two prominent spines on

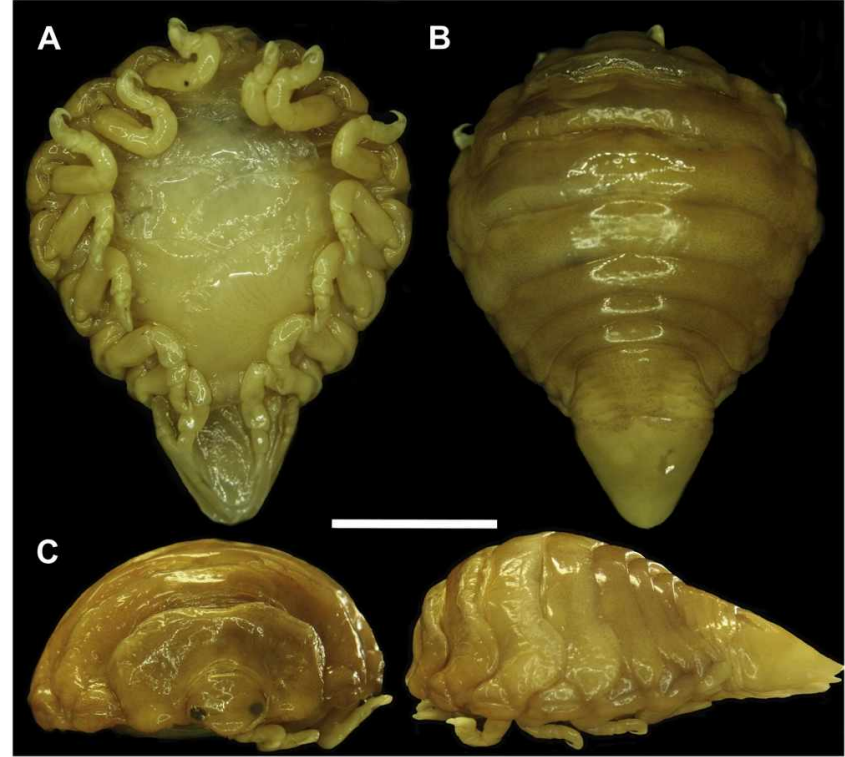

Fig. 3. The female of Riggia puyensis n. sp. A, vent ral view. B, dorsal view. C, frontal view and lateral view. Scale bar: $10 \mathrm{~mm}$.

each lobe, with scales carrying fine and numerous setae like "hairs" (Fig. $4 \mathrm{H}$ ) on outer margin, and a row of spinules on the inner margin distally. Mandibule bipartite, rounded distally and densely covered with spinulas, mandible looking to the sagittal plane. Palp shorter than mandible, with three articles; apical with a spine. Two setae on middle article inner side, basal article with one setae. Palp looking outside (Fig. 6).

Pereon with pereopods (Fig. 7A-G), curved, 1-6 with five articles and apical strong claw. Pereopod 7 without claw and longer, inner side of $3 \mathrm{rd}, 4 \mathrm{th}$, and 5 th articles with bifurcate spinules distributed in 2-3 rows across 4 th and 5 th articles, 3 rd article only on apical first third. Myxal area of pereopods with little structures like papillae, 1 st pereopod with four papillae, 2 nd pereopod with seven, 3 rd with twelve, 4th with four, 5th with six, 6th with two, and 7th with none. (Table 3).

Pleon with pleopodos (Fig. 8A-E) elongated, rounded, bilaminated (except 2nd pleopod, trilaminated), exopods ovoidal, endopods shorter than exodopods. First pleopods sharper than the others. First and second pleopod base with five spines, third pleopod with one spine, and fourth and fifth pleopod without spines. Uropod (Fig. 8F) elongated with little spines like "hairs" on the edge, pleotelson covering dorsally.

Male description (based on three specimens, measurements Table 2): Small, cephalon, not immersed in pereonite 1. Melanophores dorsally-laterally. Developed eyes (Fig. 9A-C). Antennules with 7 segments, penultimate segment with a spine, last segment with an apical spine (Fig. 10A). Antenna (Fig. 10B) with 8 segments, distal segment with a crown of spines.

Pereopods 1-6 (Fig. 11A-E) curved, with a distal segment ending in a claw. Pereopods with five segments. The penultimate segment 


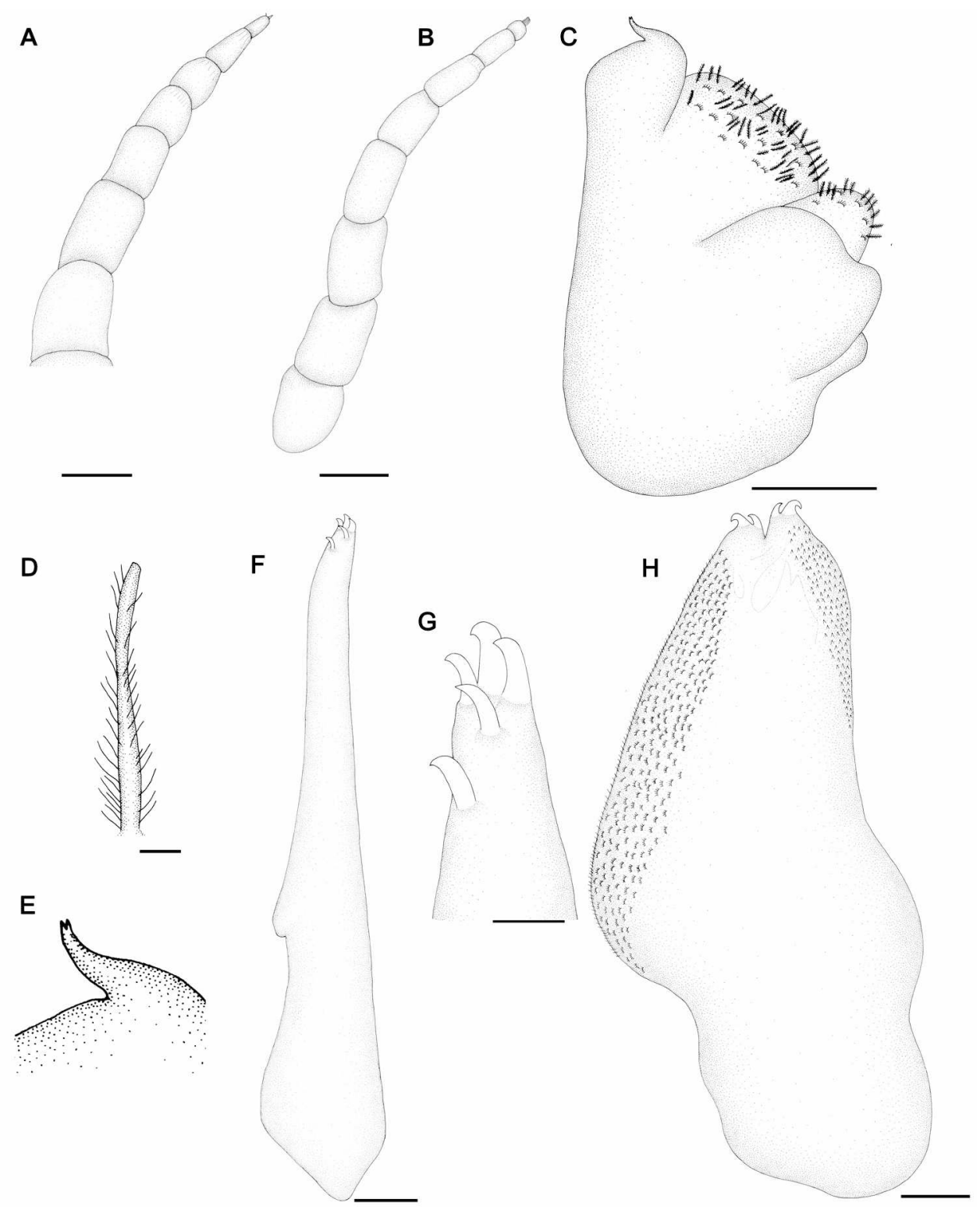

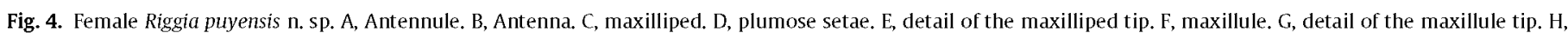
maxilla. Scale bars: A-C, F, $\mathrm{H}=300 \mu \mathrm{m}, \mathrm{D}=22 \mu \mathrm{m}, \mathrm{G}=50 \mu \mathrm{m}$.

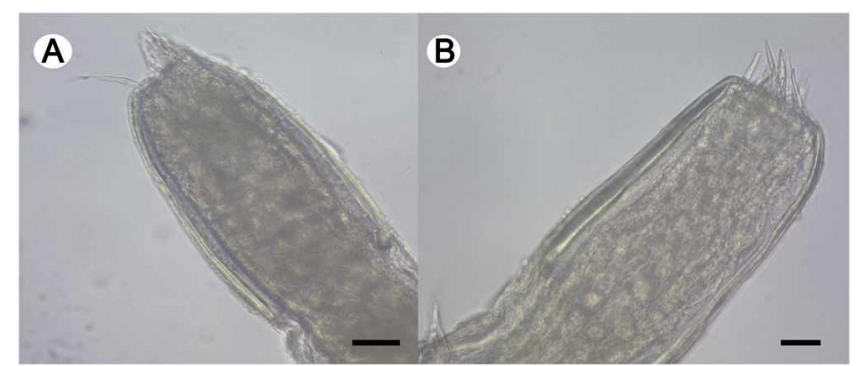

Fig. 5. Female Riggia puyensis n. sp. antennule (A) and antenna (B) detail tip. Scale bars: $A$ and $B=D=20 \mu m$.

of $3 \mathrm{rd}$, 4th and 5 th pereopods cover with little scales, similar to the female but without hairs. Claw myxal area with bifid spines, 1 st and 2nd pereopod with five spines; 3rd pereopod with four spines in the myxal area and one in the articulation of the claw, 4 th pereopod with three spines, and 5 th pereopod with four spines. Pleopods margin with long hairs (not drawn). Appendix masculinum in 2th pleopod barely visible.

Etymology: The species name "puyensis" references the principal site where fish were collected, the River Puyo.

Specimens deposited: Holotype MLP 27154, Allotype MLP 27155 collection of the Museo de La Plata, Argentina (MLP).

\section{Discussion}

The isopod specimens agree with the description of Riggia (Szidat, 1948; Bastos and Thatcher 1997 and Thatcher et al, 2002) by the presence of coxal plates fixed to pereonite I, seven pair of legs with simple dactyls and pleon - pleotelson fused.

Riggia puyensis n. sp. was found in $C$. breve and $C$. microps from the Puyo and Bobonaza rivers in Ecuador, and represents a novel site and host for this genus (the sixth reported), and the northern species of the genus. 


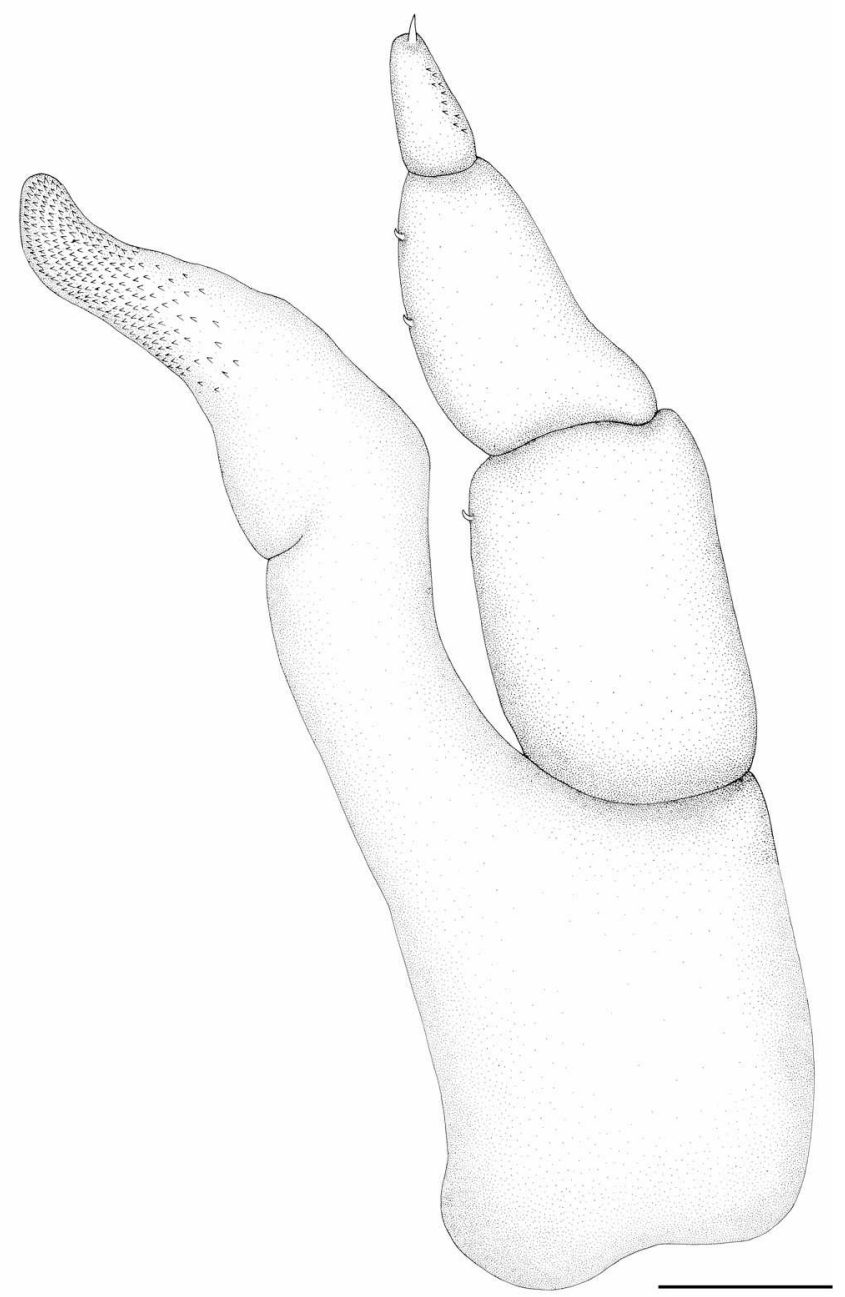

Fig. 6. Female Riggia puyensis n. sp. mandible and palp. Scale bar $=300 \mu \mathrm{m}$.

Table 2

Measurements of Riggia puyensis n. sp. compared with other species of genus.

\begin{tabular}{|c|c|c|c|c|c|c|c|}
\hline & & Riggia puyensis n. sp. & R. paranaensis & R. acuticauda & R. cyptocularis & R. brasiliensis & R. nana \\
\hline \multicolumn{8}{|l|}{ FEMALES } \\
\hline & $\mathrm{L}$ & $27,8(25-29,9)$ & $21(14-28)$ & $13,3(11-16)$ & 20 & 33 & 14 \\
\hline \multirow[t]{2}{*}{ Body } & $\mathrm{A}$ & $20,24(17,4-23)$ & $16(10-20)$ & $8,4(6-10)$ & 13 & 23 & 10 \\
\hline & $\mathrm{D}$ & $11,31(10,21-13,5)$ & & $4,3(3-5)$ & - & - & - \\
\hline \multirow[t]{2}{*}{ Pleotelson } & $\mathrm{L}$ & $13,16(10,83-15,5)$ & $7,7(5-10)$ & $3(2,5-4)$ & 6,5 & - & - \\
\hline & A & $8,14(7,2-9,5)$ & $7,2(4-9)$ & $3(2,5-3,5)$ & 5,3 & - & - \\
\hline \multicolumn{8}{|l|}{ MALES } \\
\hline & $\mathrm{L}$ & 4,37 & $6(4-8)$ & - & - & - & - \\
\hline \multirow[t]{2}{*}{ Body } & A & 1,87 & $3,5(2-5)$ & - & - & - & - \\
\hline & $\mathrm{L}$ & 1,07 & $3(1,8-4,5)$ & - & - & - & - \\
\hline Pleotelson & A & 1,12 & $1,5(1-2)$ & - & - & - & - \\
\hline
\end{tabular}

Table 3

Bifid spines and sensory setae (in parenthesis) in each pereopod and segment.

\begin{tabular}{|c|c|c|c|c|c|c|c|}
\hline & I & II & III & IV & V & VI & VII \\
\hline Propodus & $4(6)$ & $6(6)$ & $12(10)$ & $4(8)$ & $4(4)$ & $2(3)$ & $0(0)$ \\
\hline Carpus & $0(3)$ & $0(1)$ & (1) & $0(5)$ & $2(2)$ & $0(2)$ & $51(0)$ \\
\hline Merus & $0(5)$ & $0(8)$ & (5) & $0(8)$ & $0(3)$ & $0(7)$ & $47(0)$ \\
\hline Ischium & $0(7)$ & $0(15)$ & (4) & $0(0)$ & $0(16)$ & $0(0)$ & $20(0)$ \\
\hline Basis & $0(2)$ & $0(8)$ & (5) & $0(10)$ & $0(1)$ & $0(0)$ & $0(0)$ \\
\hline Coxa & $0(0)$ & $0(0)$ & $0(0)$ & $0(0)$ & $0(0)$ & $0(0)$ & $0(0)$ \\
\hline
\end{tabular}



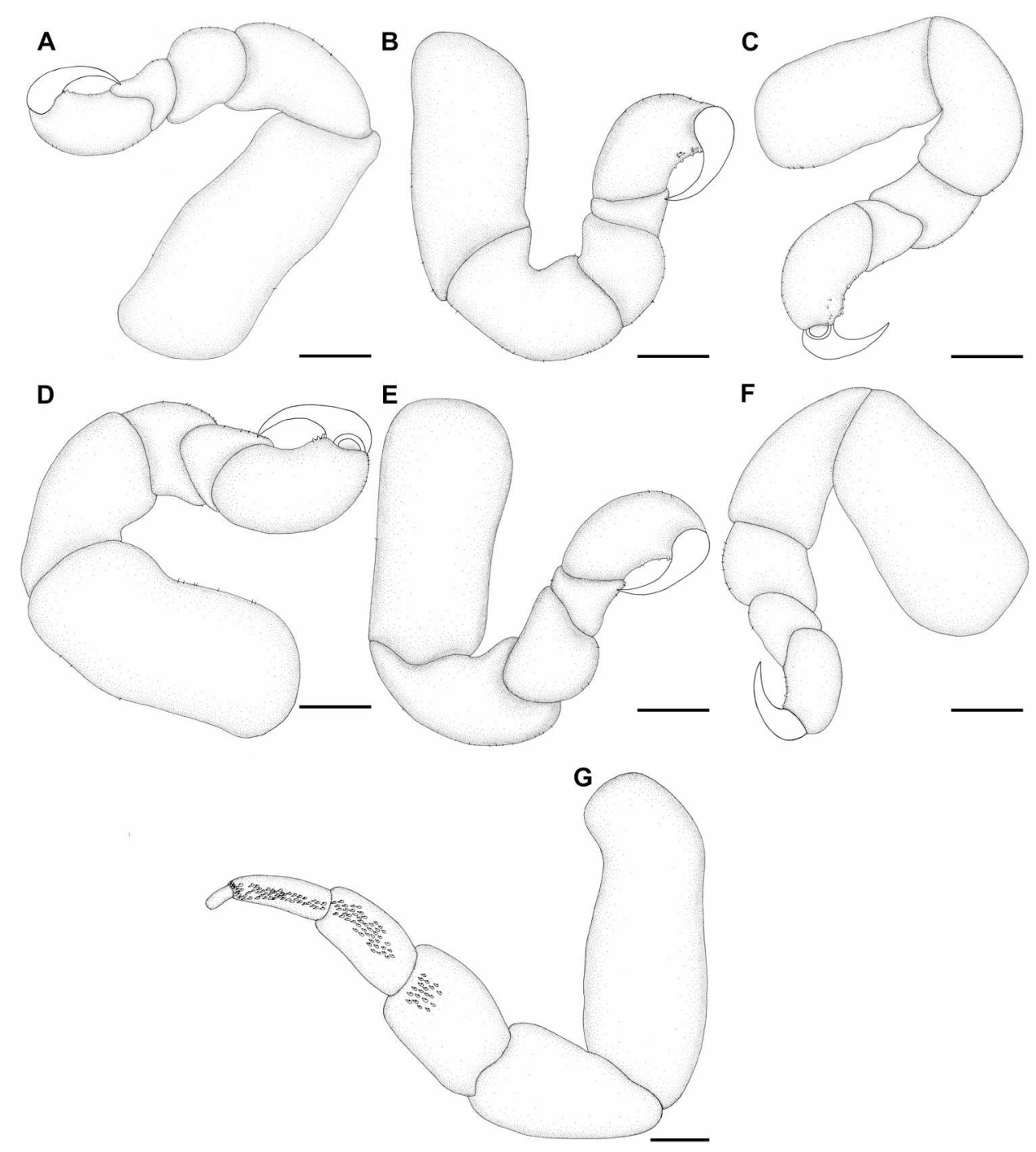

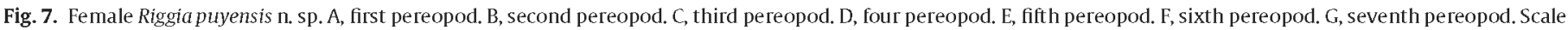
bars: $A-G=1 \mathrm{~mm}$.

The new species can be differentiating from the $R$. nana by the size. The first was poorly described by Szidat and Schubart (1960) and is smaller.

Female and male of $R$. brasiliensis are bigger than $R$. puyensis n. sp., but they appendages was poorly described by Szidat and Schubart (1960).

Riggia cryptocularis described by Thatcher et al. (2003) can be differentiate by the absence of pigmented eyes, that condition is not seen in $R$. puyensis $n$. sp. That specie was described on one female and one male, both with non functional eyes. The female antenna has 7 segments but in $R$. puyensis $\mathrm{n}$. sp. that structure has 8 segments. The plumose setae in the maxilliped are similar to the new specie, the palp have two spines (only one in R. puyensis n. sp.), and the maxillule recurved spines are three terminal and two subterminal (in the new specie the conformation is different, with two terminal, two subterminal and another spine lower). The maxilla is bi-lobed in the two species but in $R$. puyensis $\mathrm{n}$. sp. have two spines in each lobe different to the unique spine in $R$. cryptocularis. The male size is quite similar in both specie.

Riggia acuticaudata is smaller than $R$. puyensis $\mathrm{n}$. $\mathrm{sp}$., but they have well development eyes, the same number of segments in the antennule and maxilla bilobated with two spines each lobe.
In $R$. acuticauda the maxilliped have simple setae, the palp without spination, maxillule with five spines (two terminal and three subterminal) but in $R$. puyensis $\mathrm{n}$. sp. the maxilliped have plumose setae, the palp have spination (with one apical spine, two setae on middle article and one in the basal article) and the maxillule have five spines: two terminal, two subterminal and another spine lower to the others. Thatcher et al. (2002) described the pereopods without spines, which are present in the new species. The male of $R$. acuticaudata is unknown.

Riggia paranaensis poorly described by Szidat (1948) was redescribed by Bastos and Thatcher (1997) and this last work was used for the present comparison. The size of the new specie, the number of segments in the antena, and maxilla are similar between $R$. paranaensis and the new species. The antennule in $R$. puyensis $n$. sp. have 7 segments, one less than the type specie of the genus. Bastos and Thatcher (1997) when describe the antennule and antenna do not mention any spine, which are present in the new specie. The relative position of the mandible in $R$. puyensis n. $\mathrm{sp}$. is different compared with $R$. paranaensis. The maxillule have 5 spines, four terminal and one subterminal in $R$. paranaensis, but in R. puyensis $\mathrm{n}$. sp. the disposition of the 5 spines are different: two terminal, two subterminal and another spine lower to the others. 
y

A

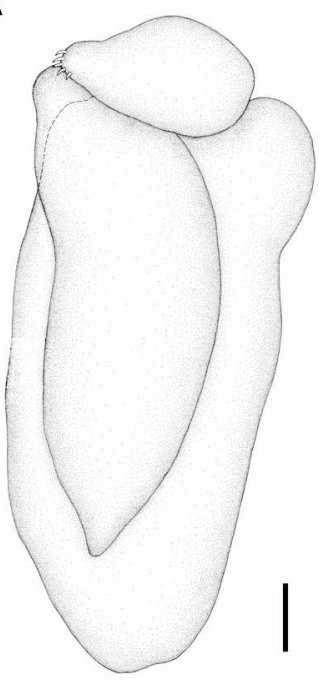

D

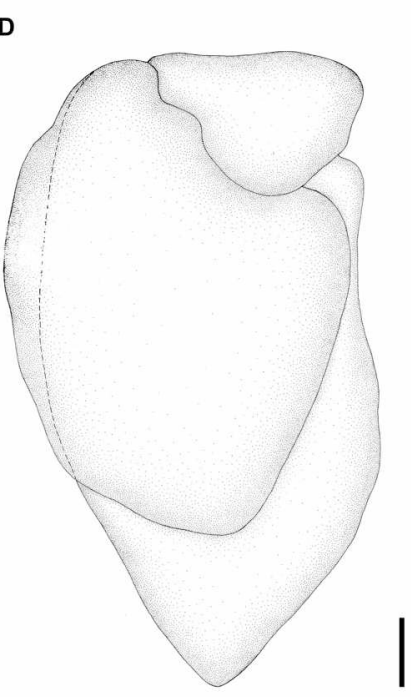

B

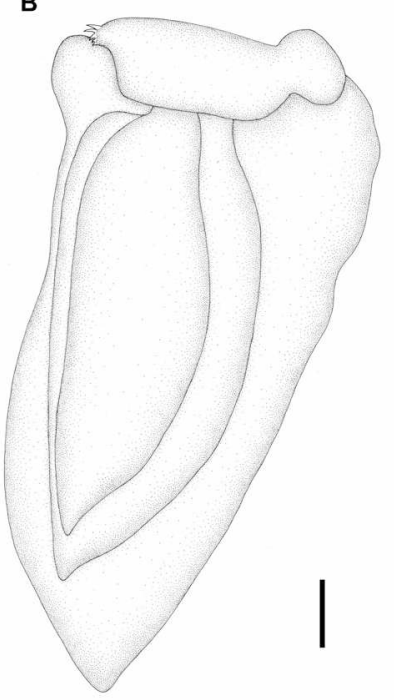

E

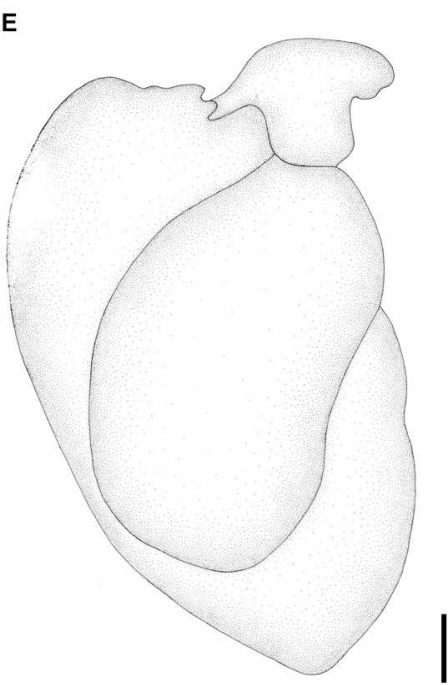

C

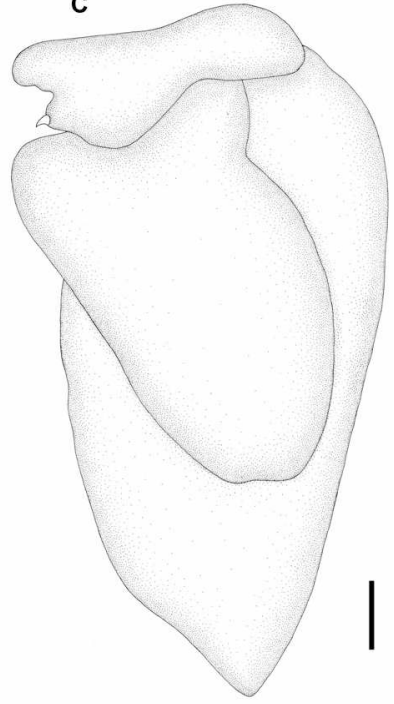

$\mathbf{F}$

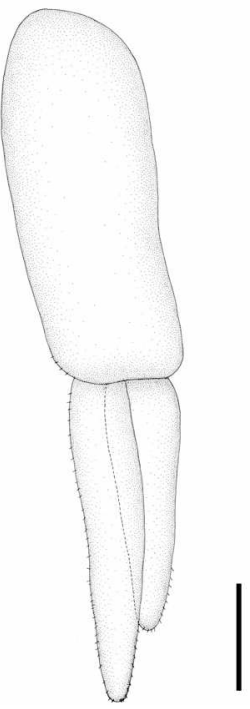

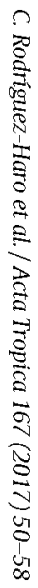

Fig. 8. Female Riggia puyensis n. sp. A, first pleopod. B, second pleopod. C, third pleopod. D, four pleopod. E, fifth pleopod. H, uropod. Scale bars: A- F= 1 mm. 

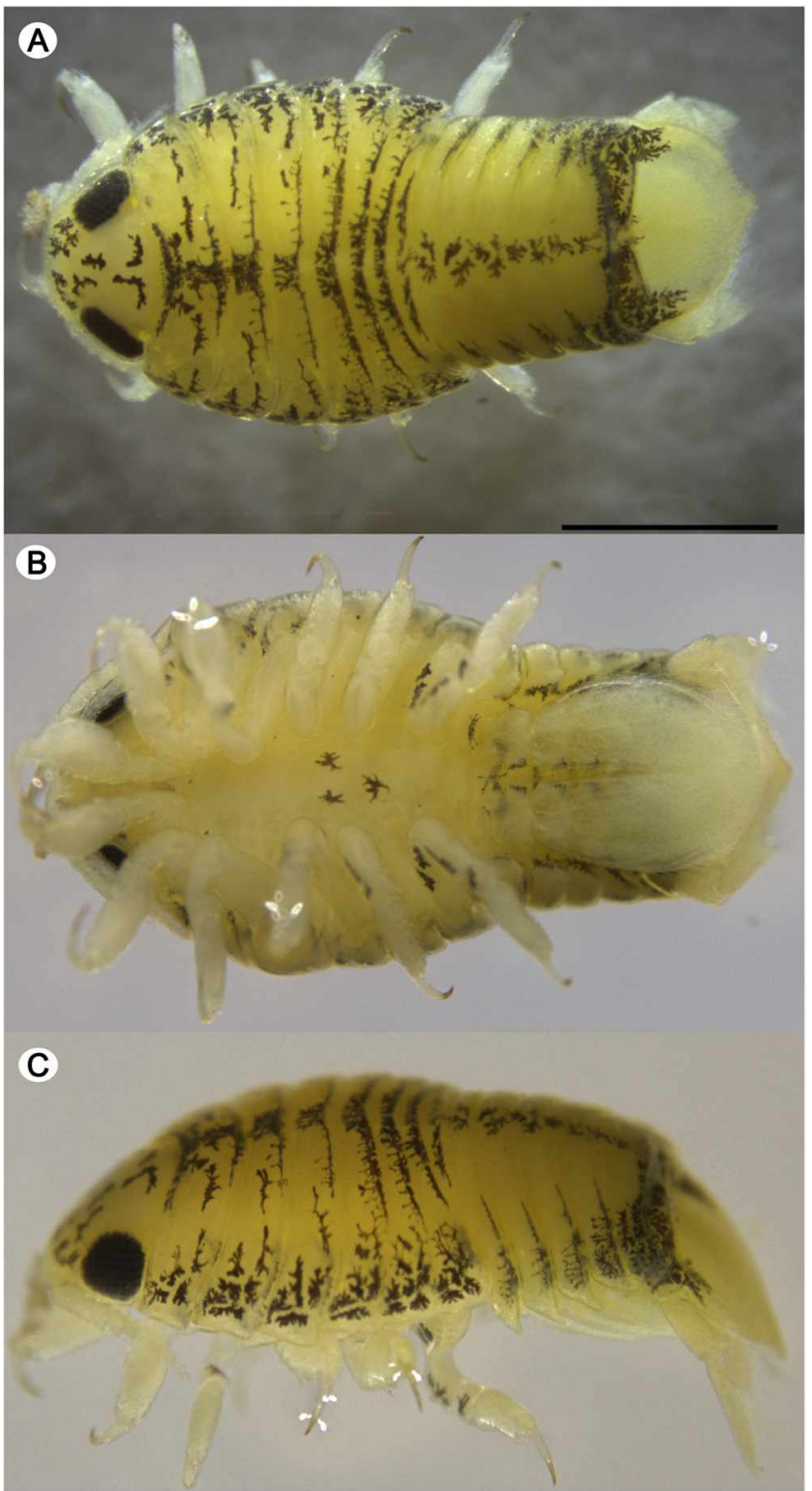

Fig. 9. Male Riggia puyensis n. sp. A, dorsal view. B, ventral view. C, Lateral view. Scale bars: $1 \mathrm{~mm}$.
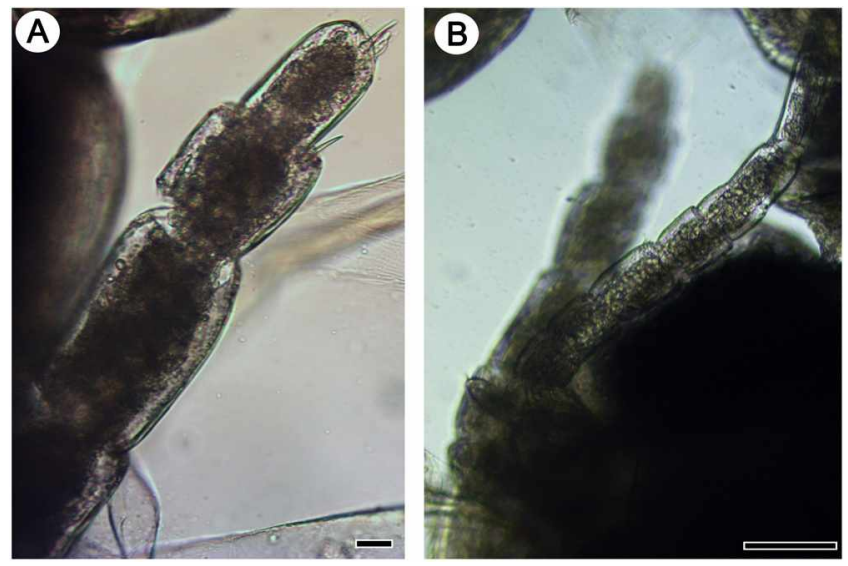

Fig. 10. Male of Riggia puyensis n. sp. antennule (A) and antenna (B). Scale bars: $\mathrm{A}=20 \mu \mathrm{m}, \mathrm{B}=50 \mu \mathrm{m}$.

The maxilliped have simple setae in $R$. paranaensis but those are plumose in the new specie. Bastos and Thatcher (1997) draw the pereopods with setae but those were not mentioned in the text. The male is similar size in both species.

Thatcher et al. (2002) report the isopod parasitizing only the left side of the abdominal cavity of the host fish, but $R$. puyensis n. sp. was found parasitizing both side.

The Riggia genus was recorded from different hosts (Ancistrus sp. Leporinus sp., Leporellus sp. Cyphocharax sp., Odontostilbe sp., Schizodon sp. and now Chaetostoma sp.) belonging to the Characiformes and Siluriformes orders. Some of those fishes are in the bottom and with low motion, but others do not share that characteristics, and only came to the bottom to feed, that could be the moment used by the isopod to be attached to the host.

\section{Acknowledgments}

We thanks to Centro de Estudios Parasitológicos y Vectores (CEPAVE), Consejo Nacional de Investigaciones Científicas y Técnicas, Universidad Nacional de La Plata (UNLP), Secretaría Nacional de Educación Superior Ciencia Tecnología e Innovación (SENESCYT) Ecuador, Instituto Nacional de Pesca (INP) Ecuador and Servicio Nacional de Sanidad y Calidad Agroalimentaria(SENASA) Argentina by permits issued of export and import of samples, Adriana Almiron and Jorge Casciotta from Facultad de Ciencias Naturales y Museo (UNLP) for fish species determination, and finally we are also grateful to Ross Procter for English editing of the manuscript.
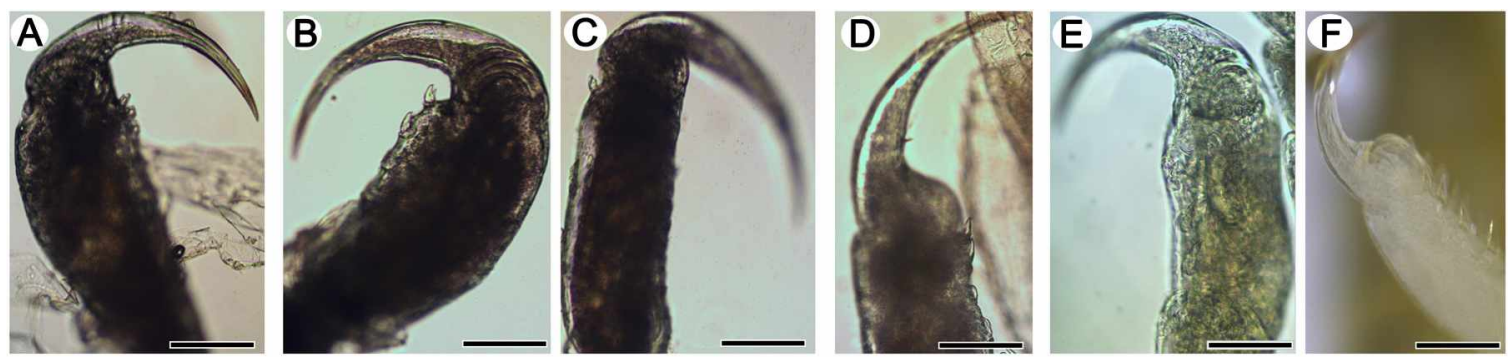

Fig. 11. Male of Riggia puyensis n. sp. A-F, first to sixth tip of pereopods. Scale bars: $\mathrm{C}-\mathrm{I}=100 \mu \mathrm{m}$. 


\section{References}

Anaguano-Yancha, F., Brito, M.J., 2015. Parasitismo de Riggia sp. (Isopoda: (ymothoidae) en dos especies de peces Chaetostoma sp. y Rhamdia quelen del suroriente del Ecuador. Av. en Cs. e Ingen. Sec. B7, 13-16.

Bastos, P.B., Thatcher, V.E. 1997. A redescription of Riggia paranensis Szidat, 1948 (Isopoda, Cymothoidae) based on thirty-two specimens from Curimatid fish of Rio de Janeiro, Brazil, with an emendation of the genus. Mem. Ins. Oswaldo Cruz 92, 755-760.

Junoy, J., 2015. Parasitism of the isopod Artystone trysibia in the fish Chaetostoma dermorhynchum from the Tena River (Amazonian region, Ecuador). Acta Trop. $153,36-45$.

Leigh-Sharpe, W.H., 1937. Badroulboudour splendida n. g. et sp.: a new parasitic isopod from Ecuador. Parasitology 29, 391-394.

Lins, D.C., Meirelles, M.E., Malm, O., Lima, N.R.W., 2008. Mercury concentration in the freshwater bonefish Cyphocharax gilbert (Curimatidae) and its parasite the crustacean Riggia paranensis (Cymothoidae). Neotrop. Ichthyol. 6, 283-288.

Oda, F.H., Da Graça, R.J., Tencatt, L.F., Tavares, L.E., Froehlich, O., Takemoto, R.M., 2015. The poorly known Riggia acuticaudata (Crustaced: Isopoda) parasitizing Ancistrus sp. (Siluriformes: Loricariidae) from the Paraguay River Basin, Brazil with comments on its reproductive biology. Comp. Parasitol. 82, 25-28.
Ortega, H., Hidalgo, M., Trevejo, G., Correa, E., Cortijo, A., Meza, V., Espino, I., 2012. Lista anotada de los peces de aguascontinentales del Perú. Estado actual del conocimiento, distribución, usos y aspectos de conservación. Ministerio del Ambiente, Dirección General de Diversidad Biológica, Museo de Historia Natural, UNMSM. Lima, Perú, pp. 58.

Sirên, A. 2004. Changing interactions between humans and nature in Sarayaku, Ecuadorian Amazon, 447. Acta Universitatis Agriculturae Sueciae: Agraria.

Szidat, L., Schubart, O., 1960. Neue und parasitiche Süsswasser-Asseln der familie cymothoidae aus dem rio mogi guassu, Brasilien (Isopoda). An. Acad. Bras. Cienc. 32, 107-124

Szidat, L., 1948. Riggia paranensis n.g. n. sp., un isópodo parásito de la cavidad de cuerpo de Curimata pistana Günther, delrío Paraná. Rev. Inst. Inves. Cien. Natur.Cien. Zool. Buenos. Aires. 1, 45-56.

Thatcher, V., Lopes, L., Froehlich, O., 2002. Riggia acuticaudata sp. nov. (Isopoda Cymothoidae) from the body cavity of a freshwater fish of Mato Grosso do Sul. Brazil. Rev. Bras. Zool. 19, 195-201.

Thatcher, V., Lopes, L., Froehlich, O., 2003. Riggia cryptocularis sp. nov. (Isopoda, Cymothoidae) from the body cavity of a freshwater fish of Mato Grosso do Sul State, Brazil. Revista Brasileira de Zoologia 20, 285-289. 